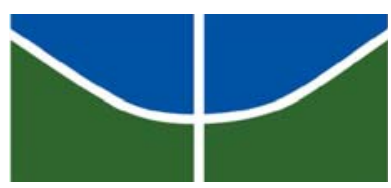

UNIVERSIDADE DE BRASÍLIA Centro de Excelência em Turismo

Pós-graduação Lato Sensu

Curso de Especialização em Formação

de Professores em Turismo

\title{
CAMINHOS PARA O DESENVOLVIMENTO \\ DO TURISMO EM POSSE (GO)
}

SMITH ADAM REGES VALENTE

Brasília - 2009 


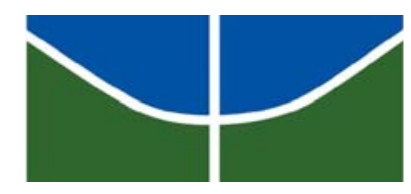

UNIVERSIDADE DE BRASÍLIA Centro de Excelência em Turismo

Pós-graduação Lato Sensu

Curso de Especialização em Formação

de Professores em Turismo

\section{CAMINHOS PARA O DESENVOLVIMENTO DO TURISMO EM POSSE (GO)}

SMITH ADAM REGES VALENTE

ORIENTADORA: PROFESSORA M.Sc. MARA FLORA LOTTICI KRAHL

Monografia apresentada ao Curso de Especialização em Formação de Professores na área de Turismo da Universidade de Brasília como requisito parcial para obtenção do titulo de especialista em Turismo.

Brasília - 2009 
Valente, Smith Adam R.

Caminhos para o desenvolvimento do turismo em Posse (GO). Smith Adam R. Valente. Brasília, 2009.

36 p.,

Monografia (especialização) - Universidade de Brasília, Centro de Excelência em Turismo, 2009.

Orientadora: Mara Flora Lottici Krahl

1. Turismo. 2. Sustentabilidade. 3. Políticas públicas.

4.Posse-GO 


\section{UNIVERSIDADE DE BRASÍLIA \\ Centro de Excelência em Turismo \\ Pós-graduação Lato Sensu \\ Curso de Especialização em Formação \\ de Professores em Turismo}

Monografia apresentada ao Centro de Excelência em Turismo - CET da Universidade de Brasília - UnB como requisito parcial à obtenção do grau de Especialista em Formação de Professores em Turismo

SMITH ADAM REGES VALENTE

Monografia aprovada em 16 de julho de 2009.

Banca examinadora:

Professora orientadora: M.Sc. MARA FLORA LOTTICI KRAHL

Professora avaliadora: Dra. IARA LÚCIA GOMES BRASILEIRO

Brasília - 2009 
Dedico este trabalho a meus pais, irmãos e especialmente a minha esposa e meus filhos, que muito me apoiaram para a conclusão deste curso. 


\section{AGRADECIMENTOS}

Ao nosso Senhor Jesus, pela motivação, orientação, paciência e força tão necessárias para condução dessa pesquisa.

À orientadora deste trabalho, pela dedicação, paciência, acompanhamento e inteligentes correções.

Em especial a meus familiares, pelas palavras de incentivo quando o corpo e a mente quiseram fraquejar.

Aos Colegas de Curso de Formação de Professores em Turismo, que quando solicitados, atenderam-me com toda atenção e carinho.

Aos meus professores, pelas palavras certas nas minhas horas incertas.

Aos funcionários do CET, pela compreensão, dedição e atenção dedicada. 
"Juntos somos fortes, somos arco e somos flecha. Todos nós no mesmo barco não há nada a temer." Chico Buarque 


\section{RESUMO}

O turismo exerce um papel de grande importância em vários países, sendo em muitos o maior meio de desenvolvimeto econômico, social e cultural. Tomando isso como base, percebeu-se a necessidade de focar as questões relacionadas ao desenvolvimento do turismo em Goiás, especialmente no Município de Posse. A presente proposta ajuda a compreender melhor as potencialidades de Posse para fins turísticos e pode subsidiar políticas e estratégias que permitam o desenvolvimento com sustentabilidade a partir da conservação e valorização dos recursos naturais e culturais.

Palavras-chave: turismo; sustentabilidade; políticas públicas; Posse (GO). 


\begin{abstract}
Tourism plays a role of great importance in several countries, and in many the greatest means of desenvolvimeto economic, social and cultural. Taking this as basis, realized the need to focus on issues related to tourism development in Goiás, especially in the City of Posse. This proposal helps to better understand the potential of tourism for Posse and should support policies and strategies for development with sustainability from the conservation and enhancement of natural and cultural resources.
\end{abstract}

Keywords: tourism, sustainability, public policy; Posse (GO). 


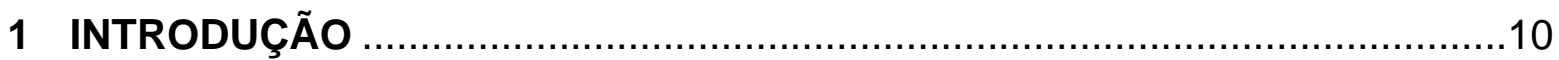

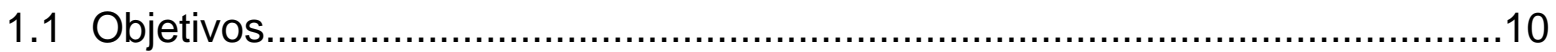

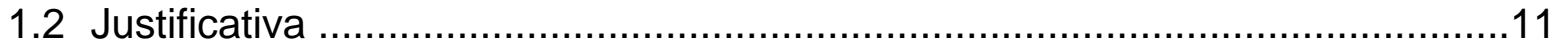

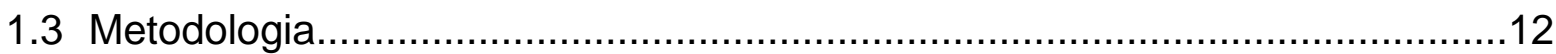

2 A ATIVIDADE TURÍSTICA EM GOIÁS - UM OLHAR SOBRE O MUNICÍPIO

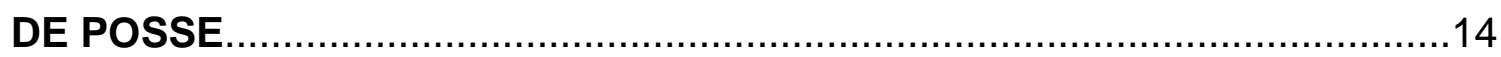

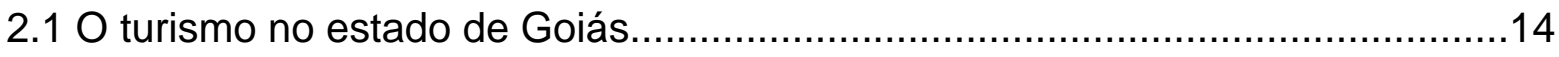

2.2 O município de Posse: aspectos gerais e contextualização

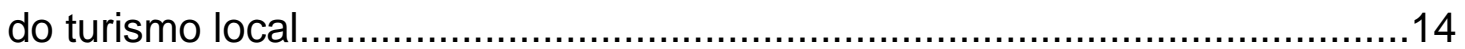

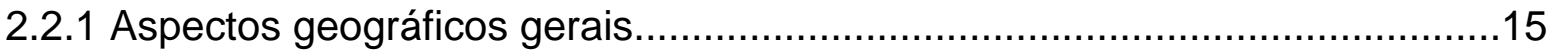

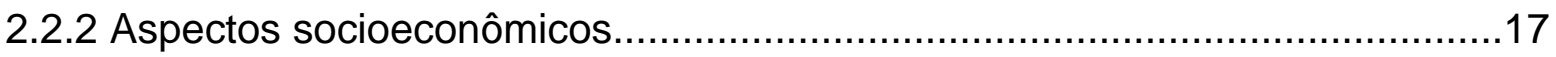

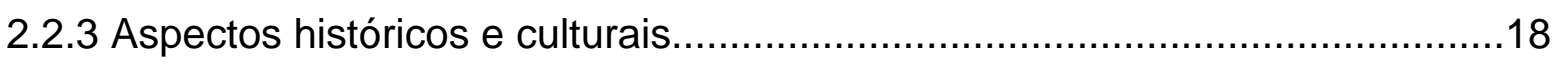

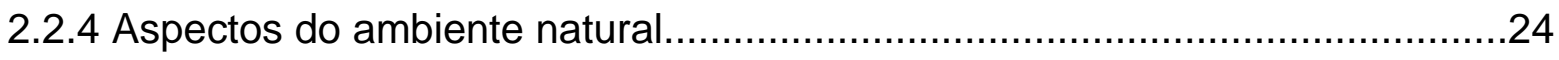

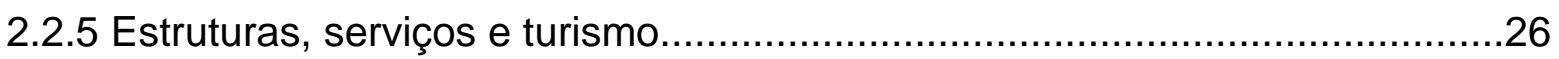

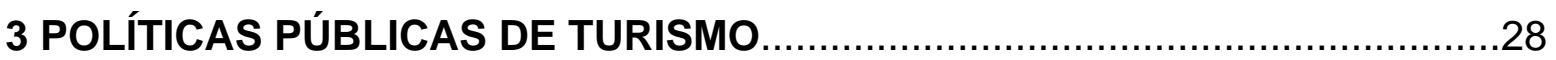

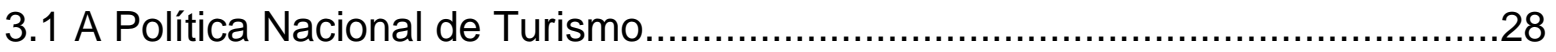

3.2 A Política Estadual de Turismo e o engajamento dos

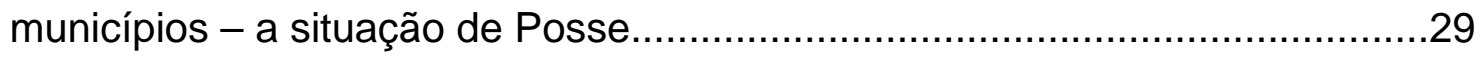

4 TURISMO: POSSIBILIDADES E ALGUMAS PROPOSIÇÕES PARA O

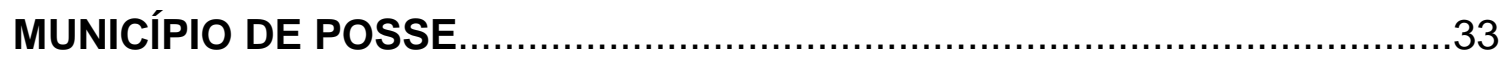

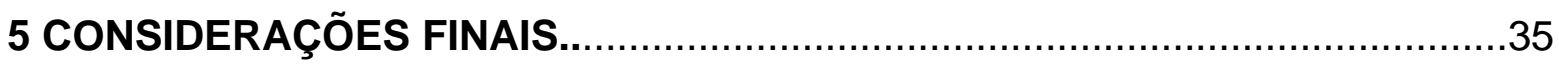

BIBLIOGRAFIA 


\section{LISTA DE ILUSTRAÇÕES}

Mapa 1. Mapa do Estado de Goiás: Mapa Rodoviario do Estado de Goiás e sua malha viária

Mapa 2. Mapa dos municípios integrantes da Região Nordeste de Goiás e sua malha viária - destaque Posse (GO)

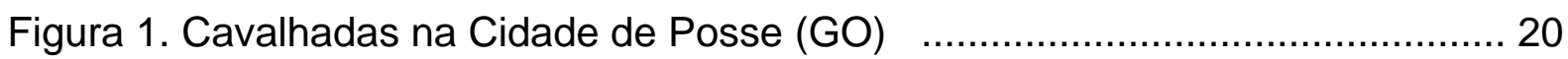

Figura 2. Cavalgada Ecológica e Cultural Posse - Terra Ronca ....................... 21

Figura 3. Cavalgada Ecológica e Cultural Posse - Terra Ronca ..........................22

Figura 4. Festa do Divino Espírito Santo Posse - GO ...................................23

Tabela 1. Tabela de Classificação de Municipios do Estado de Goiás - Região

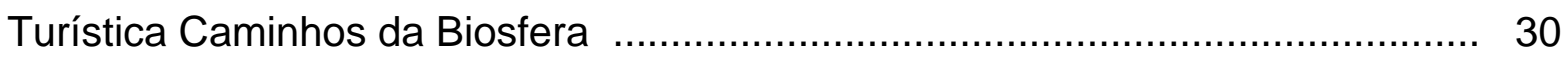

Quadro 1. Quadro de Critérios de Pontuação de Municípios do Estado Goiás. 


\section{INTRODUÇÃO}

O turismo é uma atividade que, planejada e desenvolvida com competência e empreendedorismo pode se transformar em uma importante fonte de renda para determinadas localidades. Gera empregos, evita que a população migre para outros lugares e promove os produtos locais.

Para tanto, é necessário eficiência em todas as fases do processo, desde o planejamento até a supervisão constante e realinhamento das ações em função do dinamismo do setor que requer inovação e atenção às exigências do consumidor/turista e às questões ambientais, sociais e culturais, além de outras.

É sob esse enfoque que se desdobra esta pesquisa - o turismo fomentando a valorização do meio ambiente, do patrimônio histórico e cultural e, principalmente, mostrando-se como um setor que pode efetivamente contribuir para o desenvolvimento local e regional. O estudo leva em conta o contexto do turismo no estado de Goiás - as políticas públicas e os programas implementados destacando características e perspectivas, além da dinâmica das atividades turísticas regionais tendo como ponto de partida a seguinte questão/pergunta: por que o turismo não é uma das principais atividades econômicas do município de Posse, apesar das suas potencialidades?

Com este estudo, pretende-se buscar subsídios para a elaboração de um plano de desenvolvimento do turismo na cidade de Posse (GO). Visa-se a preservar as tradições, a cultura e a história da cidade; promover o desenvolvimento local, com aproveitamento dos recursos naturais e seu uso sustentável; conquistar, gradativamente, uma clientela turística e reinvestir os recursos na região.

\subsection{Objetivos}

O objetivo principal deste trabalho é identificar possibilidades para 0 desenvolvimento do turismo no município de Posse (GO) e propor ações. Tem como objetivos específicos: analisar as políticas públicas de turismo pertinentes; apontar as potencialidades turísticas de Posse; e apontar caminhos para incentivar a atividade turística. 


\subsection{Justificativa}

As viagens para fins de lazer, descanso, saúde, negócios e outros realizadas pelo homem, desde tempos remotos, só recentemente começaram a ser encaradas como turismo, uma prática capaz de dinamizar economias e promover desenvolvimento. Conforme Troncoso (apud TULIK, 1997), nesses deslocamentos, efetiva-se um conjunto de relações humanas decorrentes da presença do turista, pelo aproveitamento e desfrute do ambiente, de seus valores naturais, culturais e sócio produtivos. Assim, por se tratar de uma atividade que viabilizada a partir do deslocamento e materializada, especialmente, com base na relação "ser humano/meio ambiente", ela deve ocorrer sob a premissa da sustentabilidade e unir a exploração econômica à valorização e à conservação do ambiente visitado.

A sustentabilidade, segundo Sachs (1993), fundamenta-se nos seguintes princípios:

- Sustentabilidade ecológica: entendida como a proteção da natureza e da diversidade biológica. Portanto, o desenvolvimento deve respeitar a capacidade de suporte dos ecossistemas, limitar o consumo dos recursos naturais e provocar o mínimo de danos aos sistemas de sustentação da vida;

- Sustentabilidade social: fundamentada no estabelecimento de um processo de desenvolvimento que promova um padrão estável de crescimento, com distribuição mais eqüitativa de renda, redução das atuais diferenças sociais e a garantia dos direitos de cidadania;

- Sustentabilidade cultural: que implica a necessidade de buscar soluções de âmbito local, utilizando-se das potencialidades das culturas especificas, considerando a identidade cultural e o modo de vida local, assim como a participação da população local nos processos decisórios e na formulação e gestão de programas e planos de desenvolvimento;

- Sustentabilidade econômica: que assegura o crescimento econômico para as gerações atuais e, ao mesmo tempo, o manejo responsável dos recursos naturais, que deverão satisfazer as necessidades das gerações futuras.

Diante disso, segundo a Organização Mundial do Turismo (OMT- 1996), o turismo só será viável se houver a conservação dos lugares turísticos essenciais, por meio de um sistema eficiente de controle de operação e planejamento. 
Enquadra-se nessa abordagem o objeto deste trabalho, isto é, uma proposta de desenvolvimento com sustentabilidade para o município de Posse, no nordeste do estado de Goiás, mais especificamente na Região Turística denominada Caminhos da Biosfera Goyás; a localização desses Caminhos apresenta-se estratégica para fins turísticos. Atualmente, Posse pode ser caracterizada com um corredor turístico, devido à movimentação de fluxos de viajantes para a região Nordeste e também dos que se destinam aos demais municípios dessa região.

A Região Caminhos da Biosfera possui recursos naturais e culturais com grande poder de atratividade, onde está incluído o município de Posse. Além disso, esse município comporta boa estrutura de hospedagem e de alimentação, conta com um comércio forte e povo hospitaleiro. A depender das políticas públicas e do envolvimento da população, essas características locais podem levar o município a evoluir de um corredor para um destino turístico no futuro.

Nessa perspectiva, a abordagem deste trabalho representa um subsídio para fins de informação e sensibilização do poder público do município de Posse e também base para a formulação de políticas para o desenvolvimento do turismo local e regional.

\subsection{Metodologia}

Entende-se que a pesquisa em turismo pode lidar tanto com problemas de natureza teórica como de natureza prática. Segundo Bortone (2009), "Os objetivos de pesquisas de natureza teórica são, entre outros, os que se seguem: descrição de fenômenos; análise do fazer turístico em algum país a partir de análise dos dados, análise documental e bibliográfica etc.".

Neste trabalho, para se identificar o potencial e verificar a viabilidade turística de Posse, foram consultados documentos históricos da cidade e adotadas diferentes perspectivas de observação, o que permitiu uma visão mais ampla do objeto estudado, para um enfoque qualitativo. Assim, esta pesquisa pode ser classificada como bibliográfica e documental.

A pesquisa bibliográfica, conforme Dencker (1998) é desenvolvida a partir de material já elaborado: livros e artigos científicos. Embora existam pesquisas apenas bibliográficas, toda pesquisa requer uma fase preliminar de levantamento de bibliografia e uma revisão da literatura, para a elaboração de um quadro conceitual e princípios teóricos. 
A pesquisa documental, segundo Gil (2007), assemelha-se à bibliográfica; a diferença entre ambas está na natureza das fontes. Enquanto a bibliográfica se utiliza fundamentalmente da contribuição de diversos autores sobre determinado assunto, a documental vale-se de matérias que não receberam ainda um tratamento analítico ou que ainda podem ser reelaboradas, de acordo com os objetivos da pesquisa.

Quanto à abordagem qualitativa, ela se caracteriza por destacar aspectos referentes à qualidade do fenômeno enfocado, procurando entendê-los, interpretálos e explicar sua relação com o contexto social.

No que se refere aos procedimentos de pesquisa, buscou-se construir um plano voltado para respostas às inquietações do investigador. Para tanto, os citados procedimentos foram seqüenciados segundo os tópicos abaixo:

- delimitação da área de estudo;

- levantamento das características de Posse (GO) em uma abordagem regional;

- coleta de dados no local de fenômeno estudado;

- análise dos dados;

- discussão e resultados. 


\section{A ATIVIDADE TURÍSTICA EM GOIÁS: UM OLHAR SOBRE O MUNICÍPIO DE POSSE}

\subsection{0 turismo no estado de Goiás}

O estado de Goiás possui vasto potencial turístico, com atrativos bastante diversificados: parques e reservas ecológicas, rios, cachoeiras, saltos, grutas, cavernas, sítios arqueológicos, serras, fontes termais, lagos, ricas manifestações culturais e construções históricas. Apresenta uma mescla de belezas naturais e de tradição, com importantes cidades históricas onde se encontram seculares festas religiosas e estruturas cosmopolitas modernas. Mesmo assim, Goiás é responsável por apenas $3 \%$ do fluxo nacional de turistas.

A chamada Região Turística Caminhos da Biosfera Goyas é composta de oito municípios: Alto Paraíso, Cavalcante, Colinas do Sul, Formosa, Guarani de Goiás, Posse, São Domingos e São João D'Aliança, que integram os roteiros da Chapada dos Veadeiros, de Terra Ronca, do Vale do Paranã e da região de Mambaí.

Não faltam opções de visitação à Região: campos, trilhas, cachoeiras, rios, grutas, piscinas naturais, canyons em meio à vegetação do Cerrado e interessantes formações rochosas. Merece destaque o Parque Nacional da Chapada dos Veadeiros, que abrange vários municípios do nordeste goiano, com destaque para Alto Paraíso de Goiás (Povoado de São Jorge) e Cavalcante, seus principais portões.

\subsection{O município de Posse: aspectos gerais e potencialidades turísticas}

O município de Posse está encravado no Vale do Paranã, entre a Chapada dos Veadeiros e a Serra Geral de Goiás. Foi cenário das muitas caravanas que por ali cruzaram: bandeirantes e viajantes nos últimos três séculos, inclusive a Coluna Prestes, em 1925.

Atualmente, é significativo o fluxo de pessoas que circulam por Posse, tanto procedentes da Bahia como de outros estados da Região Nordeste e demais regiões brasileiras. Esses turistas fazem escala na cidade e podem ser motivados à visitação 
turística no município e em seu entorno. Devido a sua localização estratégica, em função das rodovias que cortam a região, em relação à circulação de turistas e também pela boa estrutura de hospedagem e alimentação, o município se impõe como um potencial pólo, no qual o visitante pode se instalar para conhecer as belezas do Vão do Paranã e adjacências e a zona fronteiriça com a Bahia.

\subsubsection{Aspectos geográficos gerais}

Posse está a uma distância de 418 km da capital do estado, Goiânia, e a 256 km da capital do País, Brasília, dois grandes centros emissores de turistas. Limita-se ao norte com o município de Guarani de Goiás; a sudeste com Alvorada do Norte; ao sul com Simolândia; a sudoeste com Buritinópolis; a leste com Mambaí e a nordeste com Correntina (BA). Integra, com outros 19 municípios, o denominado nordeste goiano, compreendendo duas microrregiões: Vão do Paranã (composto de 12 municípios) e Chapada dos Veadeiros (com 8 municípios), numa área territorial de $38.726,364 \mathrm{~km}$, com 169.000 habitantes, correspondendo, respectivamente, a $11,39 \%$ da área total do estado e 3,37\% de sua população (VIEIRA, 2005).

Além da sede do município, Posse abarca os povoados de Barbosilândia, Nova Vista e Santo Antonio e os aglomerados de Bomba, Rodovilândia e São José. $\mathrm{O}$ acesso à cidade se dá pelos dois principais eixos rodoviários que cortam o município, o que the confere a denominação de corredor turístico entre os principais centros emissores de turistas da Região Centro-Oeste e os mais importantes destinos da região Nordeste do País: BR060/BR020/G0453, rodovia que liga Goiânia/ Brasília/Posse, e BR020, que liga Brasília/Posse/Nordeste do País.

As empresas de ônibus que operam linhas na região abrangem inclusive as cidades, distritos e povoados desprovidos de estradas pavimentadas. Quanto à malha viária regional, a partir da cidade de Posse, constitui-se das seguintes principais estradas: GO108 (Posse/Guarani), continuando com a GO110 (Guarani/ Parque de Terra Ronca/São Domingos); GO446 (Posse/laciara) e GO112 (laciara/ Nova Roma/Cavalcante/Teresina/Alto Paraíso); GO453 (Posse/BR020), e GO236 (Posse/ Mambai) (mapa 1). Segundo Real (2002), "da BR 020 chega-se a Posse, que dá acesso a Terra Ronca. Em Posse, cuja origem data do início dos anos 1800, há estrutura de restaurante e de bom descanso". 


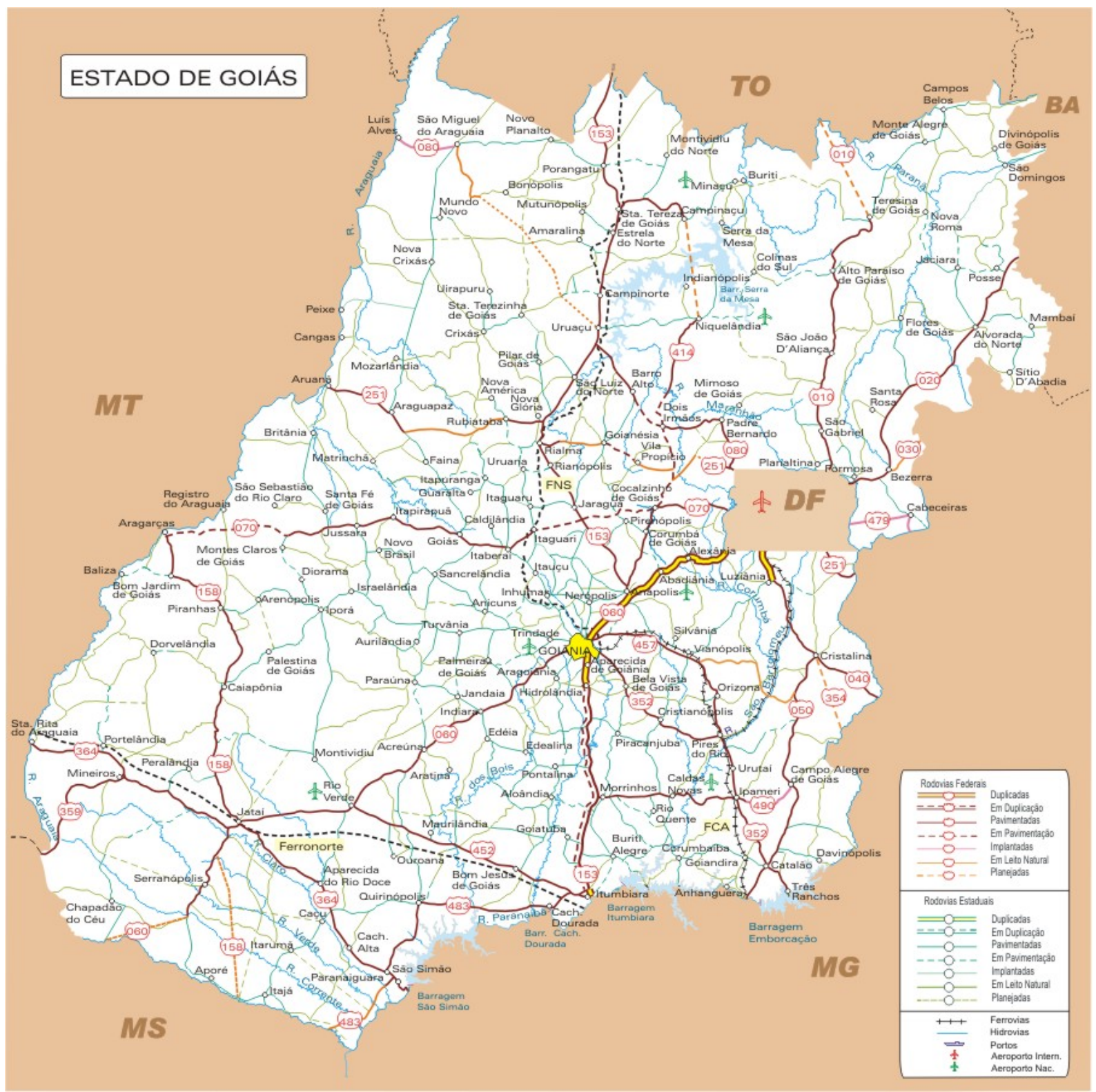

Mapa 1: Mapa Rodoviário do Estado de Goiás

Fonte: Ministério dos Transportes, 2009.

Desse modo, pode-se afirmar que Posse apresenta-se estrategicamente como ponto de conexão no caminho para diversas cidades do nordeste do estado de Goiás, tornando-se passagem obrigatória nos deslocamentos entre as regiões Centro-Oeste/Nordeste e vice-versa (Mapa 2). Segundo Vieira (2005):

Posse é o ponto da intersecção Goiás - Bahia, na rota da Rodovia Brasília - Fortaleza. A cidade é cortada em linha transversal no sentido sul, pelo córrego Passagem (antigo Passagem dos Gerais) e estende-se até a Serra das Araras, no rumo leste. Localiza-se entre duas correntezas: o Riacho das Éguas, na fazenda Vista Alegre e o Rio Prata, que nasce na Serra Geral. Devido à sua localização estratégica e à boa estrutura hoteleira, Posse atrai investimentos na área de turismo e ganha expressividade em estabelecimentos no setor de serviços. (Vieira 2005) 


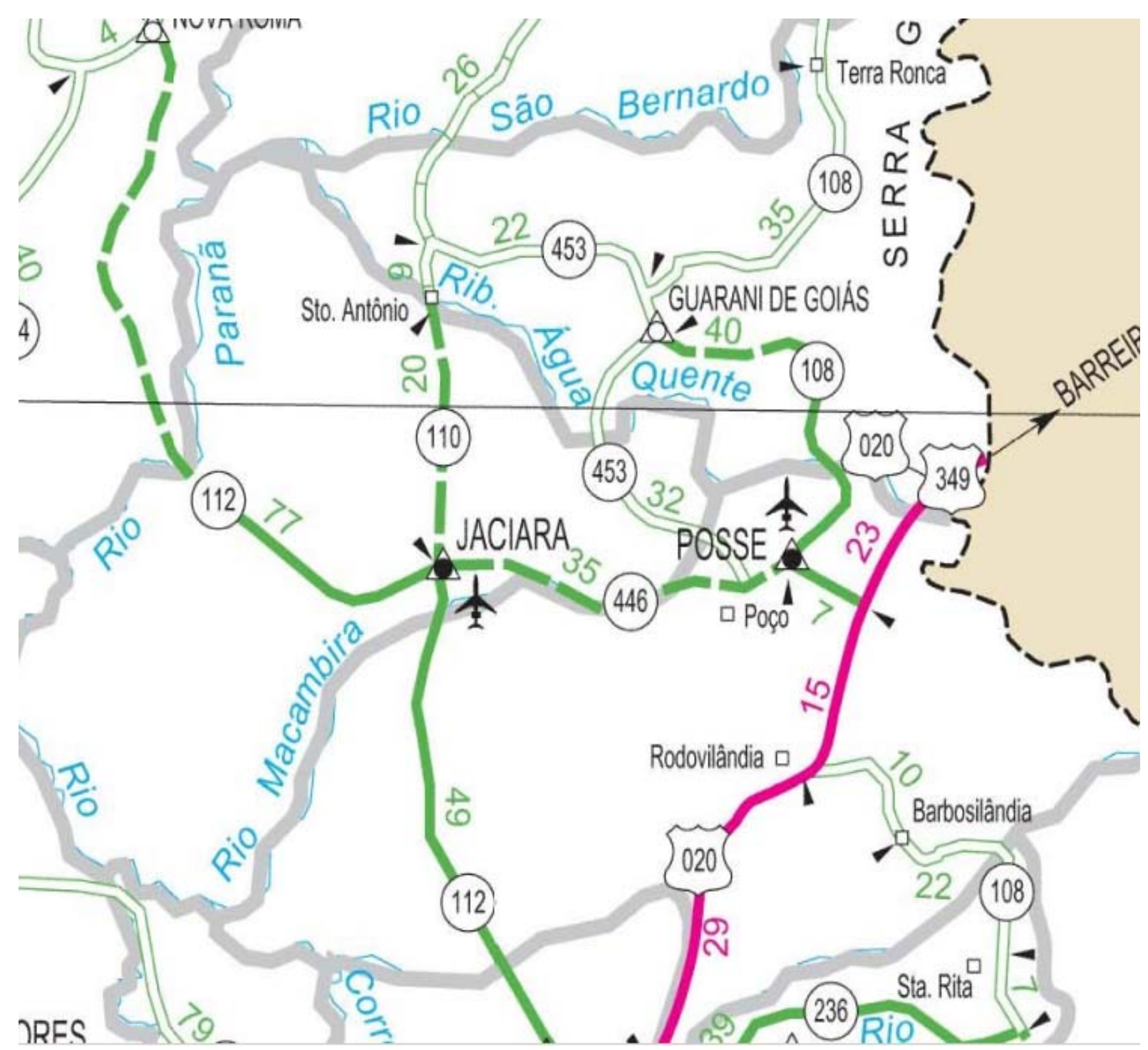

Mapa 2: Mapa Rodoviário - Nordeste de Goiás

Fonte: Sistema Estadual de Indústria Estatística e Geografia de Goiás (SIEG-GO), 2009

Além das rodovias, o município conta com um bom aeroporto, embora atue somente para táxis aéreos, pois ainda não existem linhas regulares para o transporte de passageiros.

\subsubsection{Aspectos socioeconômicos}

A população do município de Posse, em 2008, totalize 29.000 habitantes sendo 20.388 na área urbana e 9.629 na rural, de acordo com Instituto Brasileiro de Geografia e Estatística (IBGE). A principal atividade econômica de Posse, segundo esse Instituto, é o comércio, devido à grande movimentação financeira, pois o município constitui-se num centro de compras para a região, em função da sua 
localização em relação aos municípios circunvizinhos do estado e também com o município de Correntina (BA) com o qual faz fronteira. No total, atende uma população de mais de 50.000 pessoas. Merece destaque o setor agropecuário, que impulsiona o comércio principalmente com a aquisição de maquinário, de sementes, de fertilizantes e outros insumos.

Os dados relativos à produção agropecuária indicam a grande predominância dessa atividade, com formação de pastagens para a criação de gado bovino de corte. Ressaltem-se alguns volumes de sua produção em 2008: aves 35.000; ovos (1.000dz.): bovinos 92.000; suínos 3.940; vacas ordenhadas 7.000. A agricultura apresenta produção (t/ha): arroz 1.020 em 850 ha; milho 5.280 em 2.400 ha.

Nos últimos anos, houve aumento na área plantada com soja, e a tendência é de contínuo crescimento da agricultura extensiva. No entanto, persistem cultivos de subsistência, especialmente o milho, feijão, arroz e a mandioca.

Destaque-se, ainda, o Distrito Agroindustrial (DIAP), com 23 indústrias, entre elas, fábricas de papel, de tijolos e de caixas de madeiras.

\subsubsection{Aspectos históricos e culturais}

O município é rico em elementos históricos, conforme demonstra o trecho extraído de Vieira (2005, p.15):

O lugar surgiu de um aposseamento à beira do córrego Passagem dos
Gerais, ainda nos tempos de Goiás província. Os primitivos posseiros se
tornariam os futuros possenses. O governo provincial investiu, mesmo que
pouco, mas preservou também sua posse na fronteira com outras
províncias. Os homens do lugar esforçaram-se para obter benefícios da
administração provincial. Foi assim que a antiga posse se transformou em
povoado, que passou a vila, que passou a município, com o nome de Nossa
Senhora Sant'nna da Posse, que é a atual cidade-pólo do vão do Paranã.
(Vieira, 2005).

De acordo com Nogueira (1983), imigrantes nordestinos, fugindo das secas periódicas em busca de terras férteis que se prestassem à criação de gado e à lavoura, ali fundaram a primitiva povoação. Essa se localizava abaixo da confluência do rio da Prata com o rio Corrente, numa zona campestre de exuberantes pastagens naturais, que the valeu o nome de Buenos Aires, devido ao agradável ambiente local. Segundo o IBGE, os primeiros habitantes eram brancos, descendentes de portugueses, além de argentinos e uruguaios.

O povoado não progrediu devido à grande infestação de malária na época, motivo por que seus habitantes se retiraram para a zona chapadeira, fronteiriça à 
Serra Geral ou das Araras. Lá fundaram um novo povoado ao qual foi dado o nome de Nossa Senhora da Posse, Padroeira da Cidade, conservando, todavia, suas fazendas de criação, formadas às margens dos rios Paranã, Prata e Corrente.

Há relatos de que, nessas fazendas, ficaram os escravos que cuidavam das propriedades. Eles eram mais resistentes ao impaludismo, como era chamada, então, a malária. Até hoje há remanescestes desses escravos na região, especificamente nos municípios de laciara, Mambaí, Simolandia e Buritinópolis, todos outrora integrantes do município de Posse. De acordo com Vieira (2005), "Há remanescentes de colônias dispersas de negros nos atuais povoados de Três Rios, Olho D’Água da Lapa Bacupari", no município de Posse.

A denominação "Posse" é justificada pela posse do local feita pelos primeiros habitantes, que se apoderaram da faixa de terra situada à margem direita do córrego Passagem dos Gerais e escolheram como padroeira Nossa Senhora Santana da Posse. Esse fato foi relatado pelo Padre Joaquim Moreira de Carvalho, vigário-geral da freguesia de Flores, no Relatório de 15 de julho de 1830 (VIEIRA, 1988).

À Nazário da Silva Ribeiro deve-se a fundação da atual cidade, "ele construiu, além de sua residência, uma capela católica sob o orago de Nossa Senhora de Santana", segundo Vieira (2005). Em 1822, o território de Posse foi subordinado ao julgado da Paróquia de Nossa Senhora do Rosário de Flores e em 1855, foi elevado à categoria de Paróquia.

A rica história e a cultura de Posse mostram-se de diferentes maneiras. No entanto, existem poucos estudos referentes a seu patrimônio histórico e cultural, especialmente no tocante ao patrimônio material. Seu centro histórico consiste em duas praças principais e das ruas adjacentes, com destaque para outras edificações.

Mas ainda há bens de grande valor secular, como casas de fazendas e seus utensílios, rodas de fiar, pratarias, oratórios, acessórios de montarias dos antigos coronéis, esporas e bride espalhados pelo município. Tais bens constituem um acervo histórico do local, podendo-se, por meio deles, resgatar concretamente a cultura do lugar, enquanto servem de atrativo turístico.

Diversos eventos culturais são realizados no município, estando sua divulgação a cargo do Espaço Cultural Dona Mocinha, localizado no povoado do Poço. Lá, ainda se pode ver a dança do curraleiro, ícone do folclore regional. Festas religiosas como as do Divino Espírito Santo, vinculada ao domingo de Pentecostes, 50 dias após a Semana Santa, são bastante concorridas. Nessa ocasião, toda a 
população se mobiliza em giros de folias nos nove dias que antecedem as celebrações religiosas. Após essas celebrações, encena-se a cavalhada.

Segundo Bizerril (2004), a festa simboliza o dia em que o Espírito Santo desceu sobre os apóstolos. O Espírito Santo é representado por uma pomba branca, e os vários dias de celebração são encerrados com uma procissão. É, talvez, a festa religiosa mais importante de Posse e mais difundida no interior do país. Como observa o citado autor, as cavalhadas são um evento tradicional do folclore da cidade, com as encenações de batalhas medievais entre cristãos (vestidos de azul) e muçulmanos (trajando vermelho). As festas do Divino Espírito Santo constituem, realmente, cenário de grande beleza na cidade; são a maior atração da região. Ao final da batalha, os cristãos, vitoriosos, batizam os mouros, razão pela qual esse evento é considerado um momento de reafirmação de fé cristã pela comunidade.

As cavalhadas são encenadas na região desde o século XVIII. São consideradas das mais expressivas manifestações folclóricas do Brasil, chegando a ser comparada com as de Pirenópolis e as de Palmeira, ambas em Goiás. Além dos cavaleiros cristãos e mouros, há os mascarados, que usam fantasias coloridas e máscaras em formato de cabeça de boi e cavalgam pelas ruas interagindo com os visitantes (Figura 1).



Figura 1: Cavalhadas de Posse

Fonte: Fotógrafo Philippe Valente, para o pesquisador, 2008.

Existem atrações diversas no município, como tropeadas e cavalgadas com cavaleiros e amazonas de todas as idades e classes sociais, que percorrem uma distância de aproximadamente $70 \mathrm{~km}$. O trajeto é o mesmo caminho percorrido pela 
Coluna Prestes, em sua tentativa de invadir o Nordeste do Brasil, passando pelo estado da Bahia. Jorge Amado, no livro "Cavaleiro da Esperança", de 1956, fez referência a essa trajetória de Prestes: "da vila de São Domingos marcham para o Maranhão, passando por Posse, Riachão e Conceição".

Em Posse, os cavaleiros que participam da cavalgada, coordenada pela Associação Ferradura de Ouro, seguem um roteiro que torna o passeio uma aventura cultural. Aproveitando a antiga estrada Posse/São Domingos, que margeia a Serra Geral, os tropeiros passam por diversos rios de águas cristalinas, como os rios Água Quente, Puba, Bananal e o rio do Freio․ Nesses dois últimos, há uma ponte de terra e outra de pedra, feitas pela natureza. Elas são, ainda hoje, utilizadas pelos tropeiros como passarela, por ser o melhor local de travessia.

Segundo Real (2002), no km 22 da Rodovia GO/108, depois de Posse, à direita, há uma estrada de terra que leva à Ponte de Pedra, a $10 \mathrm{~km}$. É uma ponte natural em rocha, sob a qual se esconde o rio do Freio, que reaparece cerca de 100 metros adiante. Na chegada à Gruta de Terra Ronca, município de São Domingos (GO), é celebrada missa em louvor ao Bom Jesus de Terra Ronca. É esse um bom atrativo para a prática de turismo cultural e religioso (Figuras 2 e 3).

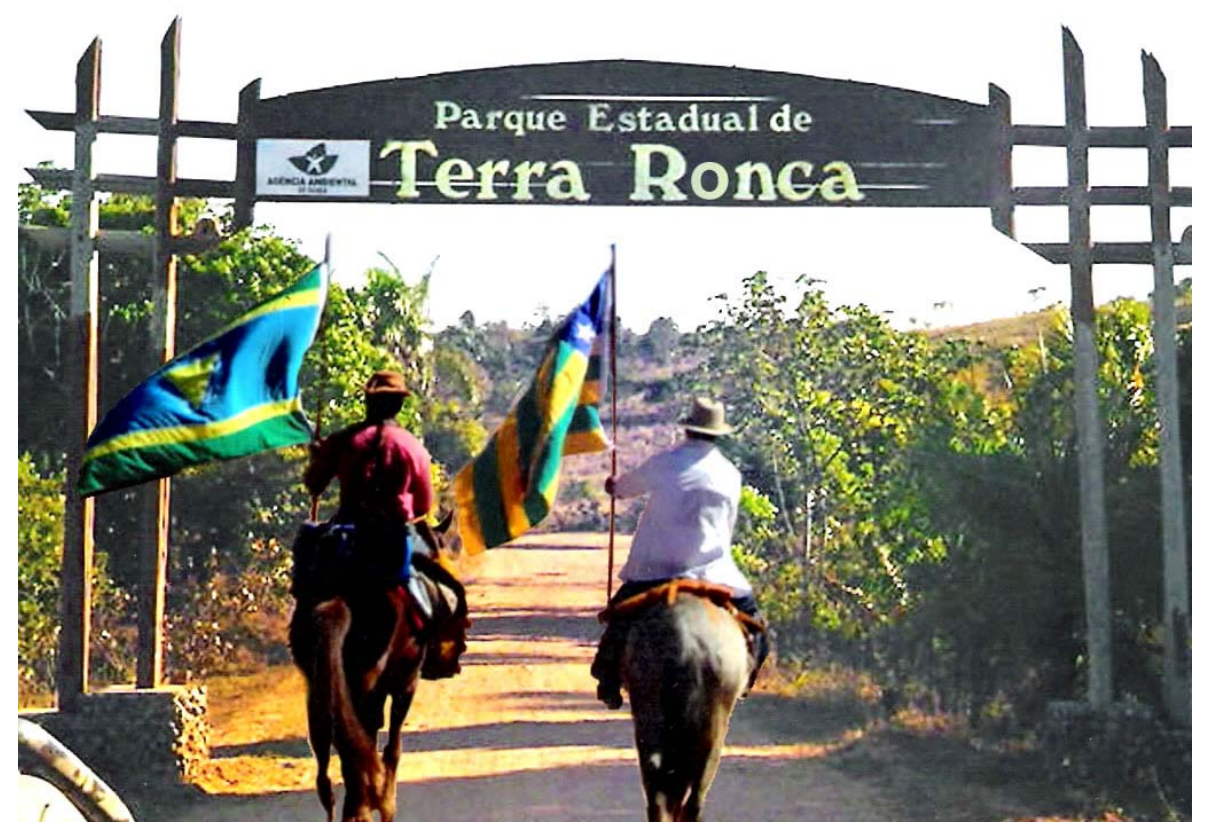

Figura 2: Cavalgada Posse Terra Ronca

Fonte: Fotógrafo Raphael Valente, para o pesquisador, 2007.

$1 \mathrm{O}$ rio do Freio originalmente denominava-se Rio do Frei, em homenagem a um frei franciscano assassinado por índios às suas margens. Passou a ser chamado de rio do Freio no linguajar regional. 


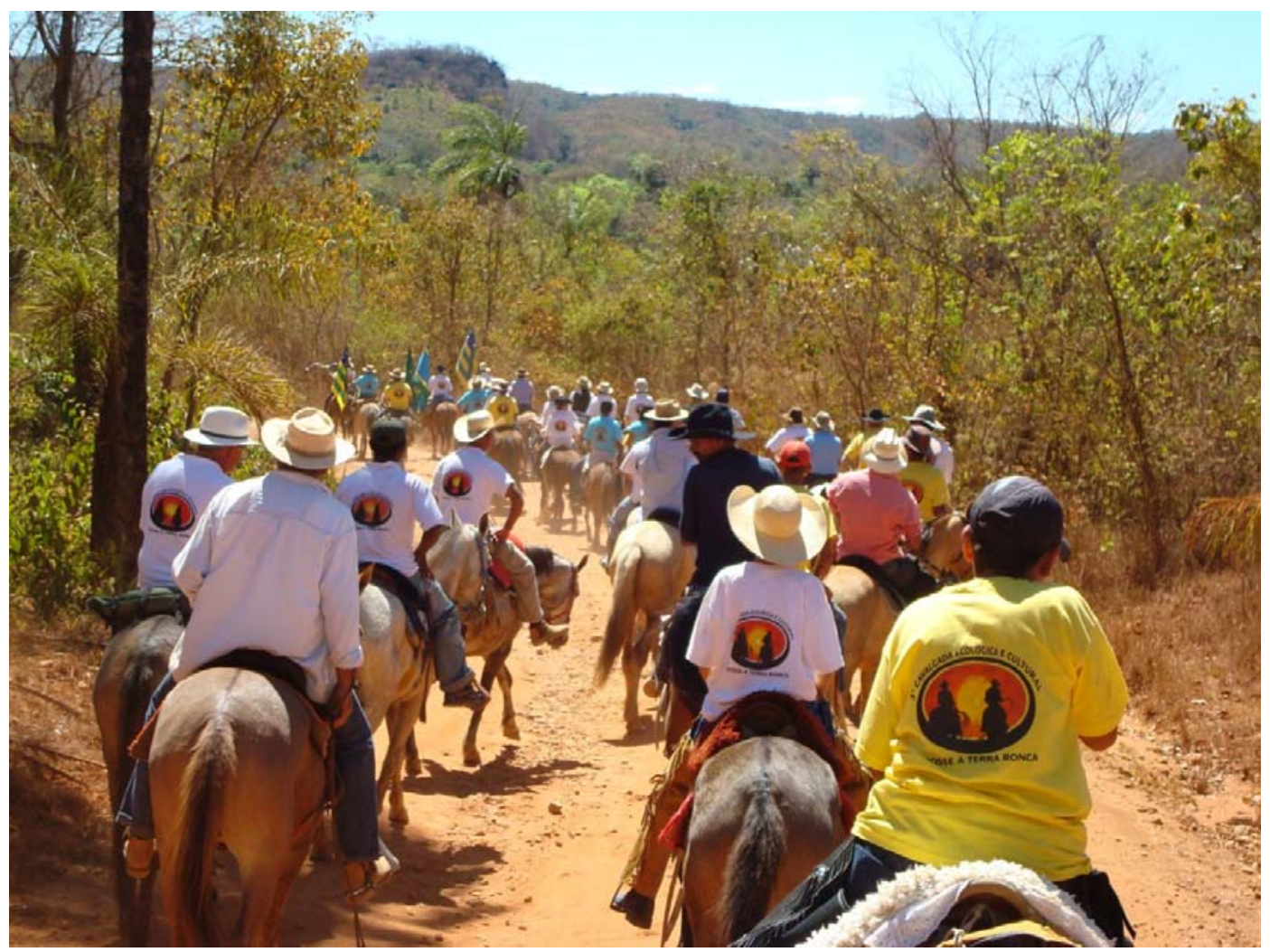

Figura 3: Cavalgada Posse Terra Ronca

Fonte: Fotógrafo Smith Valente, 2008

A comunidade possense tem seu calendário de dias santificados:

- 6 de janeiro: festa religiosa de Reis, na qual os foliões percorrem a cidade fazendo um giro nos presépios de Natal. Sempre alguém da comunidade oferece pouso aos foliões, com adoração ao Menino Jesus, e oferta de muito licor de jabuticaba e de jenipapo;

- 20 de janeiro: comemora-se São Sebastião, co-padroeiro da cidade, com folias, leilões, mastro com bandeira em homenagens ao santo;

- Semana Santa: com procissões e muitas orações. As ruas se tornam um cenário imitando a Via Sacra, a paixão e morte de Jesus Cristo;

- maio: o mês de Maria é todo festivo, sob a orientação dos festeiros eleitos pela comunidade católica. É época de barracas na rua e na última semana, são realizadas animadas quermesses, com leilões de produtos da terra;

- Festa do Divino Espírito Santo: vinculada ao domingo da Semana Santa, com cavalhadas, fogueiras e leilões onde os mascarados interagem com os visitantes e crianças da cidade (Figura 4); 


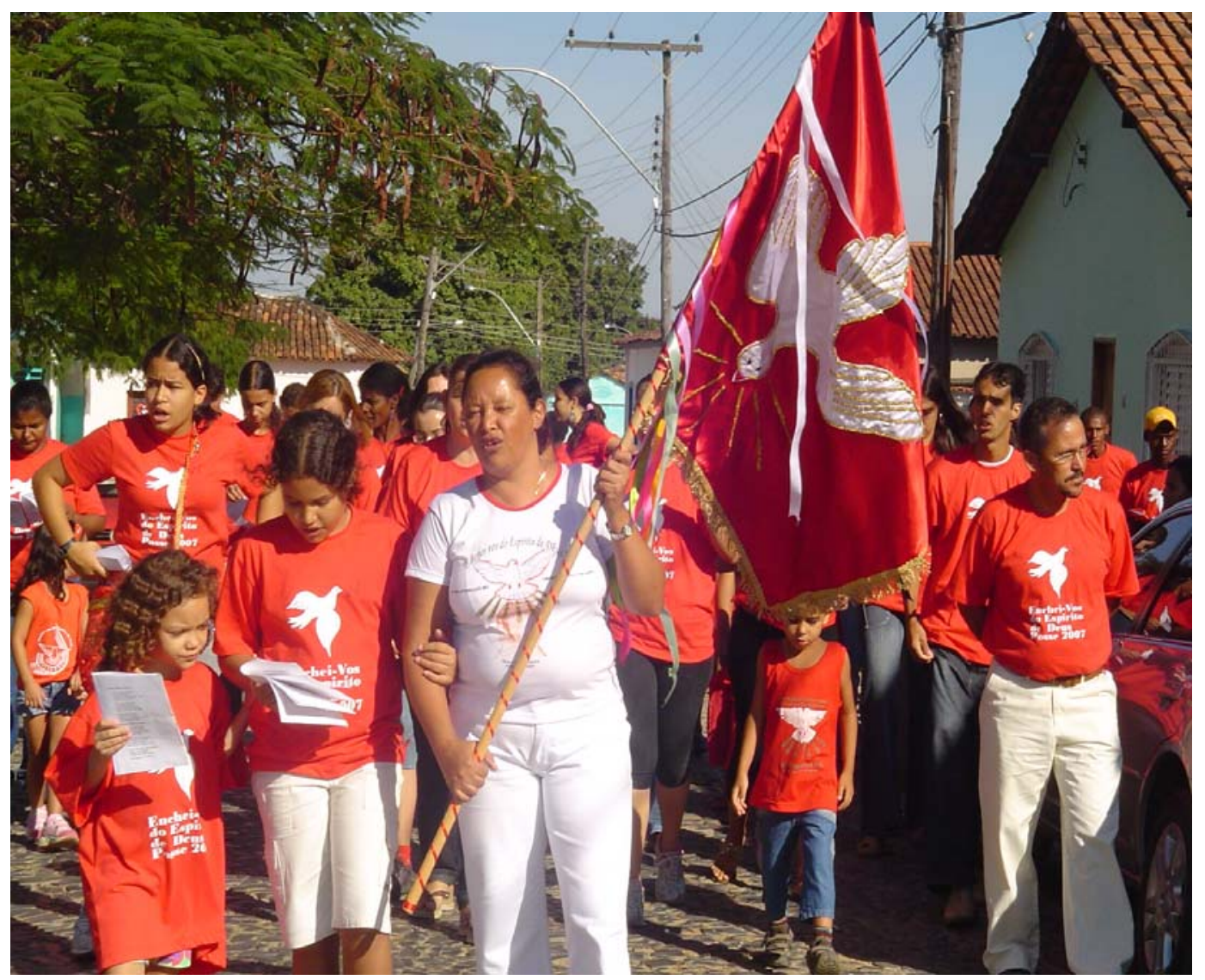

Figura 4: Festa do Divino Espírito Santo

Fonte: Fotógrafo Smith Valente, 2007

- 11 de junho, Corpus Christi: dia em que o povo da cidade arruma ruas, portas e janelas para a passagem do Senhor. Todos ajudam a arrumar as ruas com serragens coloridas, formando imagens religiosas e muitas flores; - 23 de junho: festa de São João, com apresentação de quadrilhas, fogueiras e batatas assadas. Os festejos da fogueira continuam até o dia 28 de junho, véspera da festa de São Pedro, com a fogueira dos viúvos;

- 26 de julho: festa de Senhora Santana, padroeira da cidade, animada com novenas e barraquinhas;

- mês de dezembro: festividades religiosas de Natal, com lapinhas (presépios) e distribuição de presentes.

As manifestações culturais e religiosas de Posse são algo surpreendente e contagiante. A forma como a população prepara, organiza e vivencia suas crenças e passa suas tradições de geração a geração é, sem dúvida, de uma riqueza incomparável. A comunidade, sem ficar alheia ao ritmo do progresso, vem conseguindo manter suas tradições. 
Algumas associações têm na preservação dessa tradição não só o reconhecimento da cultura como agregadora da vida humana, mas também veem nela a sustentabilidade sociocultural para fins turísticos. Porém, até o momento, suas iniciativas são tímidas; ainda não vingaram seus propósitos, principalmente por falta de apoio do poder público.

\subsubsection{Aspectos do ambiente natural}

A paisagem natural no município de Posse é formada pela maravilha da Serra Geral, denominada regionalmente Serra das Araras, que margeia toda cidade. Recentemente, foram catalogadas 70 grutas, entre elas a do Russão, a da Ponta de Terra, a da Serra das Araras e a da Vereda Olinda. Os principais rios são: da Água Quente, Buritis, Corrente, Piracanjuba, Extrema, Bezerra, Vista Alegre e da Prata, com várias cachoeiras nos três últimos. A presença do homem pré-histórico na região é testemunhada por inúmeros sítios arqueológicos, destacando-se as pinturas rupestres gravadas em rochas calcárias. O índio também deixou suas marcas e a região foi uma das primeiras do Centro-Oeste ocupada pelos bandeirantes no século XVIII.

Parte de sua paisagem manteve-se quase inalterada, apresentando importantes áreas de Cerrado preservadas, segundo Real (2002).

\section{Vegetação}

Quanto à vegetação, em todo o nordeste goiano predomina a vegetação típica do Cerrado, apresentando diversos tipos fitofisionômicos que compõem o respectivo bioma, incluindo características florísticas que anunciam o contato com a caatinga, em especial na Bacia do Rio Corrente.

Em relação ao patrimônio genético vegetal, segundo Ribeiro e Walter (1998), destacam-se famílias de grande potencial, como: Compositae, Orquidaceae, Melastomataceae, Lycopodiaceae e Xyridaceae. Muitas espécies são largamente utilizadas na medicina popular e, atualmente, são objeto de investigação cientifica, a exemplo da Arnica Montana L (Família das Asteraceae), de ação farmacológica comprovada. Outras espécies têm destacado uso madeireiro: sucupira-branca, aroeira, vinhático e ipê. Ressaltem-se, ainda, espécies com marcante interesse econômico local e regional, como o pequi, o baru, a cagaita e o buriti. 


\section{Fauna}

Levantamentos recentes atestam a riqueza e a importância da fauna regional, merecedora de estudos aprofundados. Segundo Ferreira e Tokarski (1998), registrase a presença de avifauna, composta por curiós, papagaios, tucanos, araras, seriemas e as emas, entre muitos outros. Na mastofauna, encontram-se veados campeiro e mateiro, anta, jaguatirica, onça parda, ariranha, tamanduá bandeira e tamanduá mirim, paca, ouriço caçheiro, tatu canastra, tatu bola, tatu verdadeiro, bugios, sagüis, raposinha-do-campo, lobo guará, coati, mão pelada. Há, ainda, muitas espécies de répteis, tais como osofidiosos: cascavel, jararaca, jararacuçu, surucucu; serpentes não peçonhentas como: caninana, cobra verde, cobra-d'água e achatadeira; lagartos tiú. (Ferreira e Tokarski, 1998)

Destaca-se, dos animais em extinção, a onça-pintada. A região abriga, ainda, grande diversidade de insetos, constatados 160 espécies de abelhas das quais seis inda não foram descritas pela ciência.

\section{Clima e relevo}

O clima da região é classificado como tropical semi-úmido, com temperatura média anual de $21^{\circ} \mathrm{C}$ e precipitação que varia de 1250 a $1750 \mathrm{~mm}$ anuais.

Quanto ao relevo, foi classificado como cobertura metassedimentar do rio São Francisco e Patamares do São Francisco/Tocantins. Na porção leste, encontra-se a chapada sedimentar da bacia do São Francisco. A região é marcada pela presença de ambientes cársticos, compreendendo regiões formadas por grandes extensões de rochas solúveis, geralmente calcárias, com predominância dos processos corrosivos sobre os erosivos, resultando em sistemas de drenagem subterrâneos, responsáveis pela formação de grutas, abismos e cavernas. Levantamentos possibilitaram a identificação de 65 cavidades naturais subterrâneas, com potencial para a existência de, no mínimo, o dobro dessa quantidade, segundo estudos efetuados por espeleólogos do IBAMA de Goiás (2002).

As formações cársticas (grutas e cavernas) apresentam grande fragilidade à ocupação humana e atividades como mineração, turismo e agropecuária, quando conduzidas de maneira inadequada, têm sido potencialmente nocivas ao ambiente cárstico, causando prejuízos irreversíveis. 


\section{Área de Proteção Ambiental das Nascentes do Rio Vermelho}

A necessidade de proteger o Bioma Cerrado levou à criação, em 2001, da Área de Proteção Ambiental (APA) das Nascentes do Rio Vermelho. Com uma área de aproximadamente 176.159ha, a APA compreende parte dos municípios de Buritinópolis, Damianópolis, Mambaí e Posse IBAMA (2002).

((De acordo com esse Instituto, a Unidade foi criada para: I) ordenar a ocupação das áreas de influência do patrimônio espeleológico local; II) fiscalizar a prática de atividades esportivas, culturais e científicas, e de turismo ecológico, bem como as atividades econômicas compatíveis com a conservação ambiental; III) dar ênfase às atividades de controle e monitoramento ambiental, de modo a permitir, acompanhar e disciplinar, ao longo do tempo, as interferências no meio ambiente; IV) fomentar a educação ambiental, a pesquisa científica e a conservação dos valores culturais, históricos e arqueológicos; V) proteger os atributos naturais, a diversidade biológica, os recursos hídricos e o patrimônio espeleológico, assegurando o caráter sustentável da ação antrópica na região, com particular ênfase na melhoria das condições de sobrevivência e qualidade de vida das comunidades da APA das Nascentes do Rio Vermelho e entorno; VI) implantar processo de planejamento e gerenciamento com a participação de todos os órgãos e entidades: órgãos públicos, prefeituras municipais, organizações nãogovernamentais e, principalmente, as comunidades locais (IBAMA 2002).

Ao abrigar uma das mais importantes áreas cársticas do estado, sendo considerada relevante para a conservação do meio ambiente e para o conhecimento científico, a APA representa um laboratório vivo, vislumbrando-se um pólo turístico para um futuro próximo. A categoria em questão permite a implantação de um processo de planejamento e gerenciamento com participação de órgãos públicos, organizações não-governamentais e comunidade, na busca de alternativas para um desenvolvimento sustentável. Possibilita a utilização, de forma racional e equilibrada, da imensa riqueza natural e cultural ali existente em benefício dos seus habitantes.

\subsubsection{Estrutura, serviços e turismo}

Os serviços de abastecimento de água, energia elétrica e limpeza pública atendem $\mathrm{a}$, praticamente, $100 \%$ da população urbana, e o sistema de esgoto 
tratado, a 80\% (Anuário 2007- 2008). Quanto à infra-estrutura para apoio turístico, destacam-se:

- Segurança: Delegacia de Policia;

- Transporte rodoviário: ônibus (diário) das empresas Real Expresso União, São José; transporte urbano, vans, micro ônibus, táxis; terminal rodoviário;

- Comunicação: telefones públicos; telefonia fixa e celular, sistema DDD e DDI; agência de correios; duas emissoras de rádios FM; Internet;

-Saúde: hospital municipal com 62 leitos; hospital particular com 20 leitos; Programa de Saúde da Família com 40 agentes; 10 clinicas odontológicas; 12 farmácias;

- Entretenimento: 3 ginásios de esportes; 1 estádio de futebol; 4 clubes (Aliança, AABB, Cafelândia Parque do Retiro);

- Outros: três bancos (Banco do Brasil; Bradesco; Banco Itaú); 14 oficinas mecânicas; vídeo locadoras; casas lotéricas; 20 salões de beleza (Anuário 2007 2008).

Entre os serviços e equipamentos para atender turistas, apresentam-se os principais:

- Hospedagem: são 200 leitos distribuídos em 15 hotéis, duas pousadas e 4 pensões;

- Alimentação: 6 restaurantes, 16 lanchonetes, 11 panificadoras e vários bares.( Anuário 2007 - 2008).

É preciso ressaltar a pouca qualificação dos serviços e equipamentos para a recepção e atendimento ao turista, tanto na cidade quanto nas margens das rodovias. Aliás, os equipamentos praticamente não existem na beira das estradas.

A administração municipal conta com a seguinte organização para tratar dos assuntos pertinentes ao turismo, meio ambiente e cultura: Secretaria de Educação e Cultura e Secretaria de Meio Ambiente/Diretoria de Turismo. 


\section{POLÍTICAS PÚBLICAS DE TURISMO}

\subsection{A Política Nacional de Turismo}

O turismo é considerado, hoje, uma das mais relevantes atividades econômicas no mundo. Muitos governos, percebendo sua importância, passaram a ordenar e a incentivar o setor de tal forma que, em alguns países, ele figura entre as atividades mais importantes.

No Brasil, o turismo vem sendo balizado desde 2003 pelo Plano Nacional de Turismo (PNT), ora em vigor a versão PNT 2007-2010 - Uma Viagem de Inclusão. Segundo o Ministério do Turismo (MTur), esse Plano é "um instrumento de planejamento e gestão que coloca o turismo como indutor de desenvolvimento e da geração de emprego e renda do País" (BRASIL/MTur, 2007).

Os governos estaduais, balizados pelo PNT estão, de forma participativa, através dos fóruns estaduais, discutindo e aprovando ações a serem realizadas nos municípios brasileiros, sob as orientações do Programa de Regionalização do Turismo - Roteiros do Brasil. Trata-se de um Programa dirigido para os mercados competitivos e impulsionado na perspectiva do desenvolvimento sustentável traduzido em ações, estratégias e negociação coletiva capazes de se transformar em oportunidades nos mercados mundiais e repercutir na geração e distribuição de renda no País. As diretrizes do PRT derivam 3 linhas de atuação:

Gestão coordenada: a formação de parcerias com vistas ao compartilhamento de propostas, responsabilidades e ações envolve os governos federal, estaduais e municipais, bem como a criação de instâncias que promovam a integração destes à comunidade nas etapas de planejamento, implementação e avaliação. Para efetivar tal proposta, o Programa está estruturado como uma unidade de coordenação nacional, apoiada em instrumentos metodológicos e em um sistema de informação, indispensáveis para a ação descentralizada.

Planejamento integrado e participativo: a ação pública, seja ela estatal ou privada, demanda espaços de participação política que articulam as potencialidades do conjunto dos setores sociais e econômicos envolvidos no processo de organização e gestão do território, além de possibilitar nova cultura de relacionamento. Viabilizar a elaboração de planos estratégicos de desenvolvimento do turismo regional, de forma participativa, significa democratizar os espaços e os mecanismos de representação política da sociedade civil, permitindo as mudanças estruturais almejadas.

Promoção e apoio à comercialização: na busca de adotar mudanças capazes de alterar as relações de mercado e alcançar resultados, o Programa assume pressupostos fundamentais, como vontade, inteligência, participação e o reconhecimento de que a diversidade e as particularidades do País traduzemse em diversidade e particularidades da oferta turística segmentada e, também, nos modos de comercializar. Tais pressupostos definem as etapas 
operacionais: formação de redes, educação para o mercado, formatação de roteiros, e estratégias de promoção e apoio à comercialização. (BRASIL/MTur, 2008)

Essas linhas orientam a atuação das Unidades Federadas em relação aos municípios organizados em regiões turísticas e classificados para fins de priorização quanto aos incentivos para o desenvolvimento do turismo em cada estado.

\subsection{A Política estadual de turismo e o engajamento dos municípios: a situação de Posse}

O governo do estado de Goiás via Agência Goiana de Turismo (AGETUR), seguindo o PNT, elaborou e vem implementando sua política de turismo de forma bastante objetiva, na medida da sua capacidade de execução e limitações orçamentária. Diante disso, organizou o Estado em 9 Regiões Turísticas a saber:

- Região Agro-ecológica: Jataí; Mineiros; Rio Verde, Chapadão do Céu e Serranópolis;

- Região Vale do Araguaia: Aragarças, Aruanã, Nova Crixás (Bandeirantes), São Miguel do Araguaia (Luiz Alves) e Piranhas;

- Região do Ouro: cidades de Goiás, Pirenópolis, Corumbá de Goiás, Cocalzinho de Goiás e Abadiânia ;

- Região das Águas: Caldas Novas, Rio Quente, Itumbiara, São Simão, Lagoa Santa, Buriti Alegre, Cachoeira Dourada e Três Ranchos;

- Região dos Negócios: Goiânia, Trindade, Anápolis, Aparecida de Goiânia e Hidrolândia;

- Região dos Engenhos: Cristalina, Luziânia, Silvânia;

- Região Nascente do Oeste: Paraúna, Iporá, Palmeiras de Goiás;

- Região do Vale da Serra da Mesa: Uruaçu, Minaçu, Porangatu e Niquelândia;

- Região da Biosfera Goyaz: Alto Paraíso, Cavalcante, Colinas do Sul, Formosa, Guarani de Goiás, São Domingos, São João D'Aliança e Posse.

Em cada região turística, os municípios foram hierarquizados para fins de priorização das ações de desenvolvimento do turismo, classificando-os nas categorias diamante, esmeralda e cristal (Tabela 1), com base nos seguintes critérios de pontuação elencados no Quadro 1: 


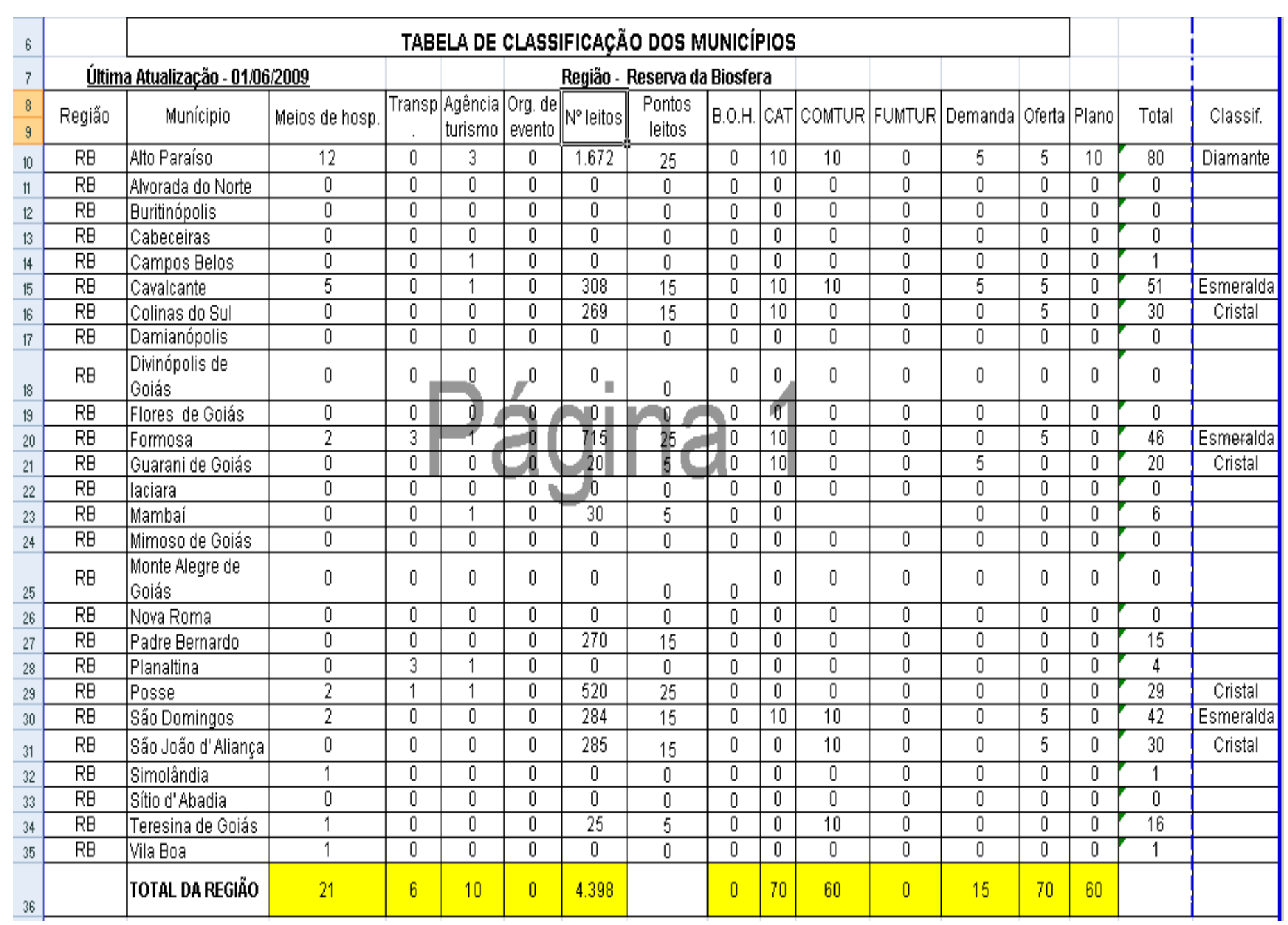

Tabela 1: Tabela de Classificação de Municípios - Região Turística Caminhos da Biosfera Fonte: AGETUR, 2008.

\begin{tabular}{|l|l|c|}
\hline \multicolumn{1}{|c|}{ Critérios } & Pontos \\
\hline 01 & Conselho Comunitário de Turismo (FUMTUR) & 15 \\
\hline 02 & Fundo Municipal de Turismo (FUNTUR) & 05 \\
\hline 03 & Inventario da oferta Turística (OIT) & 10 \\
\hline 04 & Plano Municipal de Turismo validado pelo COMTUR & 10 \\
\hline 05 & Numero de leitos disponíveis no Município & 05 \\
\hline 06 & Centro de Atendimento ao Turista (CAT) & 10 \\
\hline 07 & Cadastro dos prestadores de serviçOs turísticos: & 01 \\
& $\bullet \quad$ Agencia de Turismo & 01 \\
& $\bullet$ Empresas Organizadoras de Eventos, Congressos e Feiras & 01 \\
& $\bullet$ Meios de Hospedagens & 01 \\
& $\bullet$ Bonsportadora Turística de ocupação Hoteleira (BOH) & 01 \\
\hline
\end{tabular}

Quadro 1: Quadro de critérios de pontuação de municípios do Estado de Goiás Fonte: AGETUR, 2008.

Esse trabalho constitui-se uma estratégia para escolha dos municípios mais organizados para o turismo ao pontuar os aspectos considerados mais importantes 
para o desenvolvimento do turismo em uma localidade. Tal iniciativa é desenvolvida pelo governo e pelo trade turístico e procura envolver todos os componentes da cadeia produtiva do turismo para um objetivo comum: fortalecer o setor para conquistar novos mercados, com produtos turísticos competitivos, sob a premissa da sustentabilidade dos destinos.

A partir dos critérios apresentados anteriormente, para fins de desenvolvimento turístico, o município de Posse ficou aquém da pontuação estabelecida para se tornar prioritário ante os demais municípios da Região da Biosfera e do estado: foi classificado na categoria Cristal.

Isso quer dizer que, embora Posse apresente a referida localização estratégica e seja muito rica em recursos naturais, culturais, econômicos e outros necessários para a prática do turismo, ainda não possui iniciativas que possibilitem uma melhor inserção da cidade no mercado turístico. Falta vontade política que incentive ações de mobilização, envolvimento, organização e estruturação, a serem materializadas pela formulação e execução de políticas públicas, desde que efetivadas de forma participativa.

Nesse sentido, a gestão municipal 2001-2008, atendendo à conclamação da sociedade organizada, propôs um Projeto de Lei para a criação de uma Secretaria Municipal de Cultura e Turismo e a instituição de um Conselho Consultivo do Patrimônio Histórico e Artístico, que foi vetado pela Câmara de Vereadores sob a alegação de que o turismo não era prioridade para a Cidade.

Tal realidade foi abordada por Vieira (2005), segundo o qual "há uma problemática regional que precisa ser resolvida e isso requer a implantação de, pelo menos, três políticas fundamentais: de defesa do meio ambiente, de defesa da cultura popular e de defesa do patrimônio histórico".

Assim sendo, e corroborando com o autor supracitado, é notória a situação de quase descaso com o patrimônio cultural e natural e com o setor turístico e apresenta-se premente a efetivação de iniciativas que promovam a articulação da comunidade e dos gestores públicos em prol do interesse comum. Entende-se que tais ações tornam-se imperiosas para a viabilização de uma política de turismo para o município, pois ainda segundo esse autor, "se Posse quer exportar a imagem, que a diferencia de outras cidades da Região ou mesmo do Estado, é na fonte do turismo e da cultura popular que essa imagem está escondida" (VIEIRA, 2005, p. 25). 


\section{TURISMO: POSSIBILIDADES E ALGUMAS PROPOSIÇÕES PARA O MUNICÍPIO DE POSSE}

A análise dos principais aspectos que permitem pensar o desenvolvimento da atividade turística no município de Posse, especialmente em função das orientações oriundas das políticas nacional e estadual de turismo, leva a constatações que remetem à premência de algumas ações que dependem de vontade política e vão além da simples formulação de políticas para o setor. São imprescindíveis iniciativas emanadas da sociedade organizada, de modo participativo, a partir do fortalecimento da noção de pertencimento ${ }^{1}$ da comunidade, que devem ter um nível de clamor suficiente para sensibilizar o poder público e, efetivamente, envolver um processo de proposição, formulação e execução de políticas.

Assim, enunciam-se a seguir algumas sugestões que podem nortear gestores do setor público e do privado, comunidade e interessados no turismo como atividade capaz de gerar desenvolvimento com sustentabilidade no município e na conservação dos bens culturais e naturais como base para tanto:

1) Elaboração de um plano para o desenvolvimento sustentável de Posse, contemplando as prioridades listadas:

- Elaboração de uma política municipal de turismo integrada com políticas direcionadas para a cultura e o meio ambiente;

- Criação de Conselho Municipal tripartite (representantes do poder público, iniciativa privada e da sociedade civil) para fins dos temas turismo, cultura e meio ambiente;

- Envolvimento de empresários, população e gestores públicos nas iniciativas e processos propostos;

\footnotetext{
1 "pertencimento, ou o sentimento de pertencimento é a crença subjetiva numa origem comum que une distintos indivíduos. Os indivíduos pensam em si mesmos como membros de uma coletividade na qual símbolos expressam valores, medos e aspirações. Esse sentimento pode fazer destacar características culturais e raciais. A sensação de " pertencimento" significa que precisamos nos sentir como pertencentes a tal lugar e ao mesmo tempo sentir que esse tal lugar nos pertence, e que assim acreditamos que podemos interferir e, mais do que tudo, que vale a pena interferir na rotina e nos rumos desse tal lugar. Por outro lado, esse sentimento de pertencimento tem relação com a noção de participação. Na medida em que o grupo se sente ator da ação em curso, o que for sendo construído de forma participativa desenvolverá a co-responsabilidade, pertencendo os resultados a todos desse grupo, pois conterá um pouco de cada um." (AMARAL, 2009, verbete).
} 
- Inventariação dos recursos naturais e culturais;

- Incentivo à preservação do patrimônio histórico, cultural e ambiental;

- Efetivação de ações de tombamento, restauração e manutenção do patrimônio histórico cultural material e imaterial;

- Informação e sensibilização da comunidade como verdadeira responsável e guardiã de seus valores, especialmente a população rural;

- Promoção de ações de qualificação para o turismo;

- Criação de um centro de atendimento ao turista ;

- Incentivo a investimentos no município para a instalação de equipamentos turísticos (ex. isenção de impostos);

- Incentivo ao associativismo, especialmente para os meios de hospedagem e alimentação;

- Promoção do cadastramento obrigatório dos prestadores de serviços turísticos no MTur;

- Elaboração de um plano de marketing integrado com a região e com o estado.

Ressalta-se que as sugestões ora explicitadas requerem estreita sintonia também com iniciativas de abrangência regional, estadual e nacional, especialmente no que se refere às políticas públicas. 


\section{CONSIDERAÇÕES FINAIS}

Entende-se que o turismo nem sempre é viável ou desejável em todas as localidades. Contudo, se bem planejado, apresenta-se uma ótima alternativa de desenvolvimento, principalmente quando se almeja um desenvolvimento com sustentabilidade. Torna-se também importante aliado contra a devastação ambiental e cultural que vem ocorrendo no cerrado goiano.

No entanto, qualquer iniciativa intentada em prol do turismo, da cultura e do meio ambiente em Posse esbarra na falta de dados e informações e de vontade política, o que em muito dificultou a realização deste trabalho. Mesmo assim, pelo que se pode apurar especialmente nos trabalhos de campo, ficou demonstrado que a abordagem dessas questões beira o descaso. Tais assuntos, se tratados com responsabilidade, poderiam se transformar em elementos de apresentação de Posse para o rotineiro vai e vem de turistas, que só aportam na cidade por necessidade de escala.

Assim, para que o turismo se torne uma realidade no município, faz-se necessário um maior engajamento dos administradores locais, no sentido de alavancar a atividade de modo participativo, como uma estratégia de valorização e valoração do patrimônio local.

Enquanto isso não ocorrer efetivamente e o turismo não for colocado na pauta das prioridades, qualquer iniciativa, por melhor que se apresente, será isolada e não se reverterá em benefícios contínuos para o município.

Nesse contexto, os resultados desta pesquisa devem contribuir para embasar outras iniciativas, visto que as considerações ora registradas não constituem um fim em si mesmo. Antes, representam o início para que outros estudos possam alimentar a discussão sobre o desenvolvimento do turismo no município e incitar ações em relação aos diversos aspectos aqui abordados. 


\section{BIBLIOGRAFIA}

AMADO, Jorge. O Cavaleiro da Esperança. Vida de Luiz Carlos Prestes. 10 ed. Coleção Novos Horizontes. Rio de Janeiro, 1956.

AMARAL, Ana Lúcia. Dicionário dos Direitos Humanos, 2005. Disponível em: <www.eesmpu.gov.br/dicionario > Acesso em: 2 jul 2009.

BIZERRIL, Marcelo. Vivendo no Cerrado e Aprendendo com ele. São Paulo: Saraiva 2004.

BORTONE, S. Maris. Introdução à Pesquisa Qualitativa, São Paulo: Ed. Parábola, 2008.

BRASIL. Departamento Nacional de Infra-estrutura de Transportes. Condições das Rodovias,2009.Disponível em: <www1.dnit.gov.br/rodovias/condiçoes/go.htm> Acesso em: 30 jun 2009.

BRASIL. IBGE. Instituto Brasileiro de Geografia e Estatística. Cidades. Disponível em: <www.ibge.gov.br/cidadesat/default.php> Acesso em: 20 mar 2009.

BRASIL. IBGE. Instituto Brasileiro de Geografia e Estatística Divisão de Geociência do Centro-Oeste. Zoneamento Geoambiental e Agroecologico do Estado de Goiás: Região Nordeste. Rio de Janeiro, 1995.

BRASIL. IBAMA. Instituto Brasileiro do Meio Ambiente e dos Recursos Naturais Renováveis. Unidade de Conservação. Disponível em: <www.ibama.gov.br/go/index.php? idmenu=103> Acesso em: 20 fev 2009.

BRASIL. Ministério do Turismo. Plano Nacional de Turismo (PNT) 2007. Disponível em: <wwwnstitucional. turismo.gov.br. >Acesso em: 30 jun 2009.

BRASIL. Ministério do Turismo. Regionalização do Turismo, 2008. Disponível em: <wwwinstitucional.turismo.gov.br. $>$ Acesso em: 30 jun 2009.

DENCKER, Ada. F. Métodos e Técnicas de Pesquisa em Turismo. São Paulo: FUTURA. 1998.

FERREIRA, E.A.B.; TOKARSKI, D.J. Aspectos relevantes da saúde do Rio Tocantins. Alto Tocantins 2004. Relatório Canguás. Brasília, 2004.

GIL, Antônio Carlos. Métodos e Técnica de Pesquisa Social. São Paulo: ATLAS, 2007. 
GOIÁS. Agencia Goiana de Turismo (AGETUR). Plano Estadual de Turismo. Disponível em: < www agetur.go.gov.br > Acesso em: 25 jun 2009.

GOIÁS. Secretaria de Planejamento. Anuário 2007-2008. Disponível em: < www agetur.go.gov.br > Acesso em: 25 jun 2009.

GOIÁS. Agência Goiana de Transporte e Obras Públicas. Condições das Rodovias. Disponível em <www.agetop.go.gov.br/index.php?idEditoria=657>. Acesso em: 12 jun 2009.

GOIÁS. Secretaria de Estado do Planejamento e Desenvolvimento. Nordeste Goiano: um investimento de futuro. Goiânia: SEPLAN, s/d.

GOIÁS. Sistema Estadual de Unidades de Conservação. Unidade de Conservação Nordeste de Goiás. Goiânia: SEUC, 2009.

GOIÁS. Sistema de Indústria Estatística e Geográficas de Goiás. Base Cartográfica digital Vetorial. Disponível em < www.sieg.go.gov.br > Acesso em: 20 mar 2009.

NOGUEIRA, Armando. Goiás Distante. Goiânia: Piloto, 1983.

OMT (Organização Mundial de Turismo), o Conselho Mundial de Viagem e. Turismo e o Conselho da Terra elaboraram a Agenda 21 para a Indústria de Viagem e Turismo.< www.revistas.unifacs.br/index> Acesso em julho 2009.

REAL, Bismaque Villa. Turismo: caminhos para o turismo sustentável. Brasília: Pandéa, 2002.

RIBEIRO, J.F; WALTER, B. M. T. Fitofisionomias do bioma Cerrado. Planaltina: EMBRAPA/CPAC, 1998.

SACHS, Ignacy. Estratégias de tradições para o século XXI. In BURSZYN, Marcel (Org). Para Pensar: o desenvolvimento sustentável. São Paulo: Brasiliense, 1993.

TULIK. Olga. Do conceito às estratégias para o desenvolvimento locas. São Paulo: Hucetec, 1997.

VIEIRA, Emílio. A saga da Posse \& álbum das famílias. Goiânia: do Autor, 2005. VIEIRA, Emílio. Posse história e poesia. Goiânia: Líder, 1988 